\title{
TEORETICKÝ VÝZKUM VLIVU ZMĚNY VSTUPNÍCH PARAMETRŮ NA ÚNOSNOST A MNOŽSTVÍ SPŘAHOVACÍCH PROSTŘEDKŮ
}

\author{
THEORETICAL RESEARCH OF THE INFLUENCE OF CHANGES IN \\ INPUT PARAMETERS ON LOAD CAPACITY AND QUANTITY OF \\ SHEAR COUPLING
}

\author{
Kristýna Hrabovská*,1 \\ "hrabovska.k@fce.vutbr.cz \\ ${ }^{1}$ Vysoké učení technické v Brně, Fakulta stavební, Ústav kovových a dřevěných konstrukcí, Veveří 95, Brno, 60200
}

\begin{abstract}
Abstrakt
Tento výzkum je zaměřen na spřahovací prvky a jejich únosnost u ocelobetonových spřažených nosníků. Konkrétně se jedná o spřahovací trny s hlavou a jejich prrípadné nahrazení slepými šrouby a tím docílení demontovatelnosti konstrukce. První fáze výzkumu se zaměřila na spřahovací trny. Převážně na jejich nutné množství a rozmístění na nosníku a na to, jak změna rozměrů a materiálů ovlivní jejich únosnost. Výstupy z této fáze by měli posloužit v dalším kroku, kde budou místo trnů uvažovány šrouby a porovnána jejich únosnost.
\end{abstract}

\section{Klíčová slova}

Ocelobetonové spřažené konstrukce, spřahovací prvky, trny s hlavou, rozmístění, parametrická studie

\begin{abstract}
This research is focused on coupling elements and their load-bearing capacity in steel-concrete composite beams. Specifically shear studs and their possible replacement with blind bolts and thus achieving demountability of the structure. The first phase of the research focused on shear studs. Mainly on their necessary quantity and placement on the beam and on how the change of dimensions and materials will affect their loadbearing capacity. The outputs from this phase should be used in the next step, where the bolts will be considered instead of the studs and their load capacity will be compared.
\end{abstract}

Key words

Steel-concrete composite structures, coupling elements, shear stud, placement, parametricstudy

\section{1 ÚVOD}

Ocelobetonové spřažené konstrukce se díky svým dobrým vlastnostem stále více uplatňují ve stavebním inženýrství po celém světě. Využívají se zejména u patrových budov a při překonávání větších rozpětí. Ocelobetonové spřažené prvky kombinují př́iznivé vlastnosti obou použitých materiálů. Vysokou pevnost oceli $\mathrm{v}$ tahu a vysokou pevnost betonu $\mathrm{v}$ tlaku. Díky kombinaci obou materiálů je nalezen efektivní a hospodárný prưrèez. Významný vliv na spolupůsobení betonu a oceli má způsob jejich spřažení. V dnešní době existuje několik různých typů spřahovacích prostředků. Od dnes již často nevyužívaných blokových či úhelníkových zarážek, přes kotvy a smyčky až po nejběžnější smykové trny.

Problémem ocelobetonových spřažených nosníků je, že se nedají znovu využít a náklady na jejich odstranění jsou poměrně vysoké. Demontovatelnost spřažené konstrukce a opětovné využití ocelových profili̊ se dá zajistit využitím odnímatelných spřahovacích prvků. $\mathrm{V}$ takovém př́padě se namísto napevno navařených ocelových trnů dají využít šrouby připevněné otvory $\mathrm{v}$ pásnici I profilu. Norma [1] zahrnuje pouze postup a konstrukční podmínky pro návrh spřažení za pomoci trnů a jiné spřahovací prostředky v ní dosud nejsou zahrnuty. Jelikož šrouby s matkou mají obdobnou geometrii jako spřahovací trny, dá se díky této podobě předpokládat, že silové působení a konstrukční požadavky u návrhu pomocí šroubů budou mít jistou analogii se spřažením pomocí trnů s hlavou. 
Hlavní myšlenka tohoto výzkumu je navázat na předchozí výzkum [2] a zjistit, jak změna vstupních parametrů ovlivní nutné množství spojovacích prvků a jejich rozložení na nosníku. A jak rozměry a materiál spřahovacích prvků ovlivní jejich únosnost. První fáze studie se zabývala spřahovacími trny, pro které jsou podmínky návrhu definované $\mathrm{v}$ normě. Tato fáze je nutná pro lepší pochopení problematiky spřahování. Výstupy $\mathrm{z}$ této fáze by měli posloužit $\mathrm{v}$ dalším kroku, kde budou na místo trnů uvažovány slepé šrouby a porovnána jejich únosnost s trny.

\section{POPIS SOUČASNÉHO STAVU}

Norma zahrnuje pouze výpočet plného a částečného spřažení za pomoci spřahovacích trnů s hlavou, ostatní druhy spřahovacích prvků se navrhují na základě zkoušek a výzkumů. Nejčastěji se dnes uplatňují smykové trny, jejichž největší výhodou je, že mají stejnou únosnost ve všech směrech. U nás i ve světě se část výzkumů kompozitních konstrukcí zaměřuje na nové typy spřahovacích prostředků, jako jsou například perforované lišty, kterými se zabývá tým z ČVUT v Praze pod vedením prof. Studničky [3].

Samostatnou kapitolou jsou demontovatelné spřahovací prostředky. Výzkum na únosnost slepých šroubů a jejich následnou demontovatelnost provedl společný tým z australských univerzit [4]. Jejich výsledky ukazují, že únosnost šroubů dosahuje přibližně $95 \%$ únosnosti navařených trnů. Záleží na konkrétním typu použitého šroubového spoje. Problematikou u použití šroubových spojů je i počáteční prokluz způsobený vůli vyvrtaného otvoru pro šroub, který sice neovlivní celkovou únosnost, ale může mít vliv na chování při provozním zatížení. Studii porovnávající slepé šrouby bez matky nebo s jednoduchou či dvojitou zapuštěnou matkou provedl pomocí modelování tým $\mathrm{z}$ univerzity Putra $\mathrm{v}$ Malajsii [5]. Experimentálně výzkum s různými typy slepých šroubů a jejich porovnání s přivařenými šrouby provedl tým z univerzity ve Vietnamu [6].

Všechny tyto výzkumy se zabývali převážně porovnáním různých typů slepých šroubů, nikoli jejich optimalizací dle rozměrů, materiálu nebo rozmístění ani vlivem změny vstupních parametrů ocelobetonového nosníku na jejich únosnost. Tento výzkum si klade za cíl zjistit, jak jednotlivé parametry ovlivní únosnost spojovacích prvků a jejich množství. První fáze je zaměřena na spřahovací trny, pro něž existují podklady pro navrhování a v další fázi se trny nahradí slepými šrouby.

\section{METODIKA}

Návrhová únosnost spřahovacího trnu s hlavou se stanoví dle vztahu

$$
P_{R d}=\min \left\{\frac{0,8 \cdot f_{u}}{\gamma_{v}} \cdot \frac{\pi \cdot d}{4} ; \frac{0,29 \cdot \alpha \cdot d^{2} \cdot \sqrt{f_{c k} \cdot E_{c m}}}{\gamma_{v}}\right\}
$$

kde $f_{\mathrm{u}}$ je mez pevnosti trnu, $\gamma_{\mathrm{v}}$ dílčí součinitel spolehlivosti materiálu, $d$ průměr dř́ku, $\alpha$ korekční součinitel závisející na poměru výšky a průměru trnu nabývající hodnot $0,8-1,0, f_{\mathrm{ck}}$ je charakteristická pevnost betonu a $E_{\mathrm{cm}}$ sečnový modul pružnosti betonu.

Při výpočtu v pružné oblasti se uvažuje, že smyková síla působící na jeden trn odpovídá nárůstu normálové síly v betonu, což lze vyjádřit vzorcem

$$
V_{L, e l}=\frac{V_{E d} \cdot S_{c}}{n \cdot I_{i}} \cdot S_{l}
$$

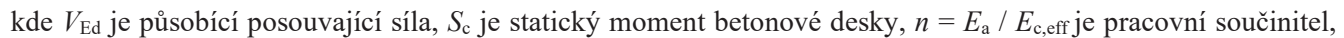
$I_{\mathrm{i}}$ moment setrvačnosti ideálního průřezu a $S_{1}$ udává rozteč spřahovacích prostředků.

Podmínka spolehlivosti udává, že poměr smykové síly a počtu spřahovacích prostředků v příčném směru musí být menší než návrhová únosnost $P_{\mathrm{Rd}}$. Z této skutečnosti a z rovnice (2) se dá tedy vyjádřit minimální možná rozteč trnů na nosníku, aby byla podmínka spolehlivost splněna, jako

$$
S_{l}=\frac{P_{R d} \cdot n_{r} \cdot n \cdot I_{i}}{V_{E d} \cdot S_{c}}
$$

kde $P_{\mathrm{Rd}}$ je návrhová únosnost spřahovacího prvku, $n_{\mathrm{r}}$ počet spřahovacích prostředků $\mathrm{v}$ příčném směru, $n$ pracovní součinitel, $I_{\mathrm{i}}$ moment setrvačnosti ideálního prưřezu, $V_{\text {Ed }}$ působící posouvající síla a $S_{\mathrm{c}}$ statický moment betonové desky. Potom podělením délky nosníku minimální roztečí spřahovacích prvků se získá minimální nutný počet trnů na nosníku. 
Při plastickém výpočtu na prostém nosníku se vychází z předpokladu, že smyková síla odpovídá síle v betonové desce. Za předpokladu, že neutrální osa prochází betonovou deskou, tak smyková síla odpovídá síle $\mathrm{v}$ tlačené části betonu, která má shodnou velikost jako síla působící na ocelový profil. Proto lze smyková síla spočítat dle vztahu

$$
V_{L, p l}=N_{c}=N_{a}=f_{y d} \cdot A_{a}
$$

kde $N_{\mathrm{c}}$ je síla v tlačené části betonu, $N_{\mathrm{a}}$ síla působící na ocelový profil, $f_{\mathrm{yd}}$ návrhová mez kluzu oceli a $A_{\mathrm{a}}$ je průřezová plocha ocelového nosníku.

Potom se nutný počet trnů na polovině rozpětí prostého nosníku spočítá ze vztahu

$$
n_{f}=\frac{V_{L, p l}}{P_{R d}}
$$

kde $V_{\mathrm{L}, \mathrm{pl}}$ je smyková síla působící na nosníku a $P_{\mathrm{Rd}}$ návrhová únosnost spřahovacího prvku.

Tento výzkum navazoval na předchozí práci [2], kde byly měněny čtyři parametry a zkoumán jejich vliv na momentovou únosnost. Konkrétně se jednalo o výšku betonové desky $h_{\mathrm{c}}$, pevnost betonu $f_{\mathrm{ck}}$, mez kluzu oceli $f_{\mathrm{y}}$ a plochu ocelového profilu $A_{\mathrm{a}}$. Při procentuální změně po desítkách procent u zkoumaných parametrů dochází i ke změně nutného počtu trnů pro spřažení oceli s betonem. Na návrhovou únosnost spřahovacího prvku má z pozorovaných veličin vliv pouze změna pevnosti betonu, kdy s rostoucí $f_{\mathrm{ck}}$, narůstá i hodnota $P_{\mathrm{Rd}}$. Při výpočtu $\mathrm{v}$ pružné oblasti s rostoucí výškou, at' už betonové desky, či ocelového profilu, klesá síla na jeden spřahovací trn a tím narůstá rezerva $v$ jeho odolnosti. A při plastickém výpočtu se mění nutný počet šroubů pouze při změně ocelového nosníku, a to jak při změně jeho rozměrů, tak i při změně meze kluzu oceli. Se zvětšujícím se průřezem nebo rostoucí pevností oceli je nutný vyšší počet trnů. Zde dochází k jistému paradoxu, kdy změna velikosti IPE průřezu zdánlivě vyvolá opačnou reakci v plastické a pružné oblasti, jak je vidět na Obr. 1. Zatímco u větších profilů v pružné oblasti dochází ke snížení síly působící na spřahovací trn a stačilo by zde tedy i jejich menší množství, tak u plastického výpočtu vychází, že je zapotřebí čím dál většího množství spřahovacích prostředků. Tento protiklad je zapř́íčiněn tím, že u pružného výpočtu vstupuje do výpočtu skutečné zatížení nosníku ve formě posouvající síly, zatímco u plastického výpočtu skutečné zatížení nikde nefiguruje. Pružný výpočet je založen na předpokladu plné plastifikace, tedy že $M_{\mathrm{Ed}}=M_{\mathrm{pl}, \mathrm{Rd}}$. Proto u pružného výpočtu se zvětšující se plochou průřezu dochází k nárůstu nutného počtu trnů, jelikož počet trnů zde není vztažen ke skutečnému zatížení působícímu na nosník, ale k plastické momentové únosnosti, která se s rostoucí velikosti profilu, také zvětšuje a udává tedy počet trnů nutný pro plné spřažení při plném využití daného průřrezu. Při plném spřažení už s dalším přidáním spřahovacích prvků nedochází k nárůstu momentové únosnosti.



Obr.1 Graf ukazující počet trnů při plastickém a pružném výpočtu při změně velikosti IPE profilu.

Často nedochází k plnému využití prưřezu, a proto je možnost snížit množství trnů pomocí částečného spřažení viz. Obr. 2, kdy je zaveden tzv. stupeň smykového spřažení $\eta$, který udává podíl mezi skutečně použitým množstvím trnů $n$ a počtem nutným pro úplné spřažení při plně využitém průřezu $n_{\mathrm{f}}$. Při částečném spřažení se nová ohybová únosnost uvažuje

$$
M_{R d}=M_{p l, a, R d}+\left(M_{p l, R d}-M_{p l, a, R d}\right) \cdot \eta
$$

kde $M_{\mathrm{pl}, \mathrm{a}, \mathrm{Rd}}=W_{\mathrm{pl}, \mathrm{y}} \cdot f_{\mathrm{y}}$ je momentová plastická únosnost ocelového nosníku, $M_{\mathrm{pl}, \mathrm{Rd}}$ ohybová únosnost a $\eta$ je stupeň smykového spřažení.

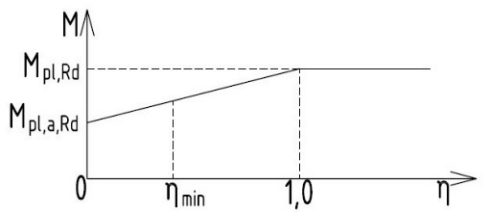

Obr. 2Graf zobrazující velikost momentové únosnosti v závislosti na stupni smykového spřažení. 
Dosazením skutečného ohybového momentu na nosníku $M_{\mathrm{Ed}}$ do rovnice (6) na místo požadované únosnosti $M_{\mathrm{Rd}}$, dosazením podílu počtu trnů za stupeň smykového spojení $\eta$ a využitím rovnice (5) můžeme vyjádřit vztah pro počet trnů dle skutečného zatížení

$$
n=\frac{V_{L, p l}}{P_{R d}} \cdot \frac{M_{E d}-M_{p l, a, R d}}{M_{p l, R d}-M_{p l, a, R d}}
$$

Tento vztah má význam jen pro hodnoty ohybového momentu větší než momentová plastická únosnost ocelového profilu.

Z konstrukčních zásad vyplývá i hodnota minimálního stupně spřažení

$$
\eta_{\min }=\max \left\{0,4 ; 1-\left(\frac{355}{f_{y}}\right) \cdot\left(0,75-0,03 \cdot L_{e}\right)\right\}
$$

kde $f_{\mathrm{y}}$ je mez kluzu oceli a $L_{\mathrm{e}}$ délka mezi nulovými momenty v metrech (u prostého nosníku je rovna skutečné délce nosníku). Potom se nejmenší možný počet trnů spočte vynásobením rovnice (5) hodnotou $\eta_{\min }$.

Pro lepší názornost bylo při zkoumání vlivu změny parametrů nosníku uvažováno s počtem spřahovacích prvků dle skutečného momentu, ale současně limitovaného minimální hodnotou trnů dle konstrukčních zásad a počtem trnů pro dosažení úplného spřažení.

\section{VÝSLEDKY}

Jako základní vzorek pro parametrickou studii byl zvolen prostě podepřený ocelobetonový spřažený nosník délky $8 \mathrm{~m}$. Průřrez byl tvořen betonovou deskou o efektivní šířce $b_{\text {eff }} 2000 \mathrm{~mm}$ a výšce $h_{\mathrm{c}} 80 \mathrm{~mm} \mathrm{z}$ betonu C20/25 a profilem IPE $200 \mathrm{z}$ oceli S 235.

Změna IPE profilu vyvolá změnu jak jeho plochy, tak i dalších parametrů jako jsou výška, průřezový modul nebo moment setrvačnosti. Mezi těmito veličinami byly zjištěny závislosti, tak aby další porovnání výsledků bylo závislé jen na jedné proměnné x udávající změnu plochy průřezu. Závislost parametrů na ploše průřrezu byla zkoumána na konkrétních typech nosníků řady IPE, jejichž hodnoty byly vyneseny do grafu a aproximovány, takže byly získány rovnice určující závislost mezi proměnnými.

Parametrická studie byla provedena za pomoci tabulkového procesoru, kdy byl sledován počet spřahovacích prostředků $\mathrm{v}$ závislosti na procentuálním nárůstu parametru $\mathrm{x}$, který udával poměr nové hodnoty sledované veličiny ku hodnotě původní. Sledovány byly změny výšky betonové desky, pevnostní třídy betonu i oceli a změna IPE průr̆ezu.

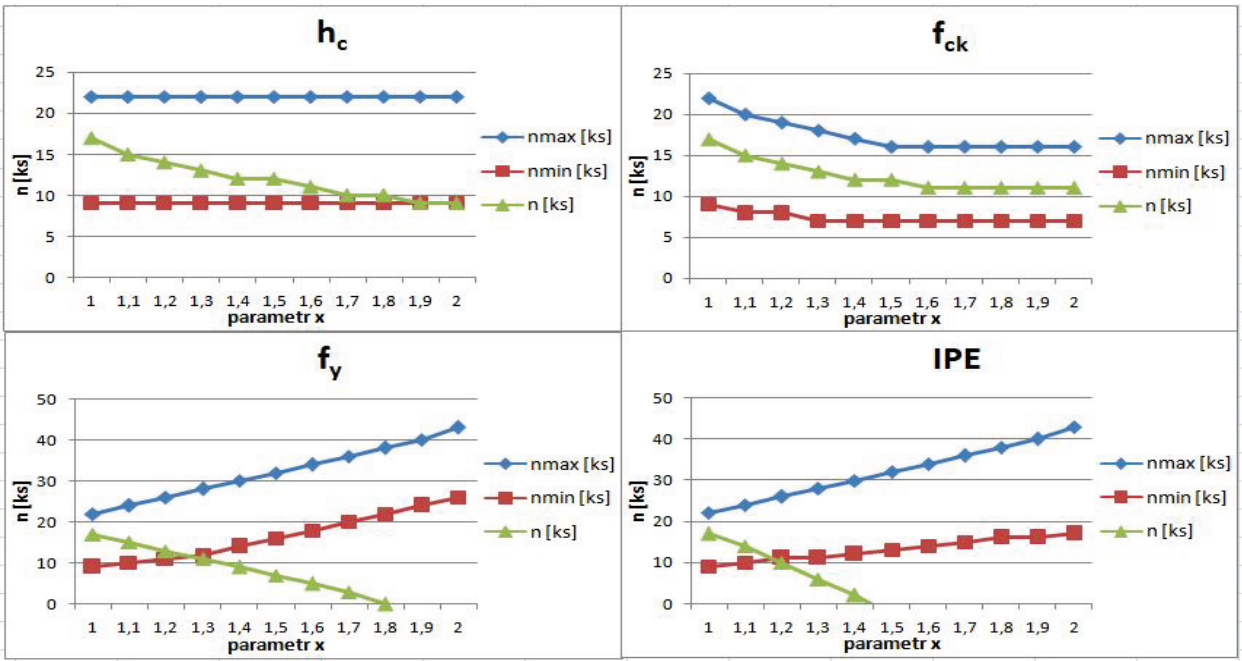

Obr. 3 Grafy závislosti maximálního a minimálního počtu trnů a počtu trnů dle zatížení v závislosti na změně parametru jednotlivých vstupních veličin. 
Tab.1 Počet skutečného množství spřahovacích trnů v závislosti na nárůstu parametru x, udávajícího poměr nové hodnoty sledovaného parametru ku původní veličině.

\begin{tabular}{ccccc}
\hline $\mathbf{x}$ & $\begin{array}{c}\mathbf{n}[\mathbf{k s}] \\
\text { pro změnu } \mathbf{h}_{\mathbf{c}}\end{array}$ & $\begin{array}{c}\mathbf{n}[\mathbf{k s}] \\
\text { pro změnu } \mathbf{f}_{\mathbf{c k}}\end{array}$ & $\begin{array}{c}\mathbf{n}[\mathbf{k s}] \\
\text { pro změnu } \mathbf{f}_{\mathbf{y}}\end{array}$ & $\begin{array}{c}\mathbf{n}[\mathbf{k s}] \\
\text { pro změnu IPE }\end{array}$ \\
\hline $\mathbf{1 , 0}$ & 17 & 17 & 17 & 17 \\
$\mathbf{1 , 1}$ & 15 & 15 & 15 & 14 \\
$\mathbf{1 , 2}$ & 14 & 14 & 13 & 11 \\
$\mathbf{1 , 3}$ & 13 & 13 & 12 & 11 \\
$\mathbf{1 , 4}$ & 12 & 12 & 14 & 12 \\
$\mathbf{1 , 5}$ & 12 & 12 & 16 & 13 \\
$\mathbf{1 , 6}$ & 11 & 11 & 18 & 14 \\
$\mathbf{1 , 7}$ & 10 & 11 & 20 & 15 \\
$\mathbf{1 , 8}$ & 10 & 11 & 22 & 16 \\
$\mathbf{1 , 9}$ & 9 & 11 & 24 & 16 \\
$\mathbf{2 , 0}$ & 9 & 11 & 26 & 17 \\
\hline
\end{tabular}

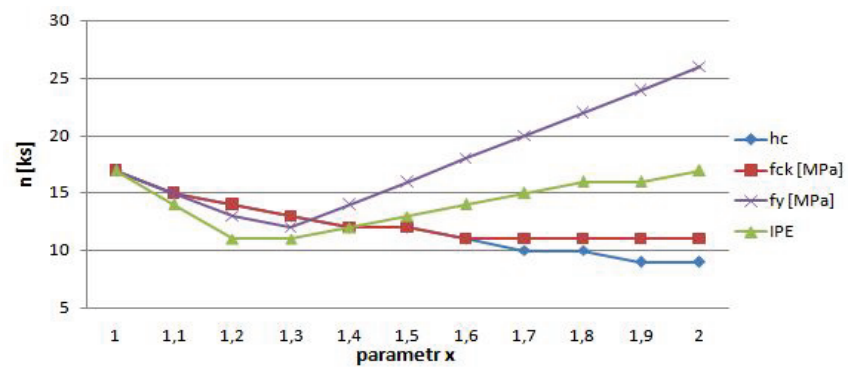

Obr. 4 Graf skutečného počtu trnů v závislosti na parametru x.

Obdobně byly měněny i parametry spřahovacích trnů, jako je jeho délka, průměr dříku a třída oceli. Tyto změny byly provedeny dle skutečných hodnot proměnných.

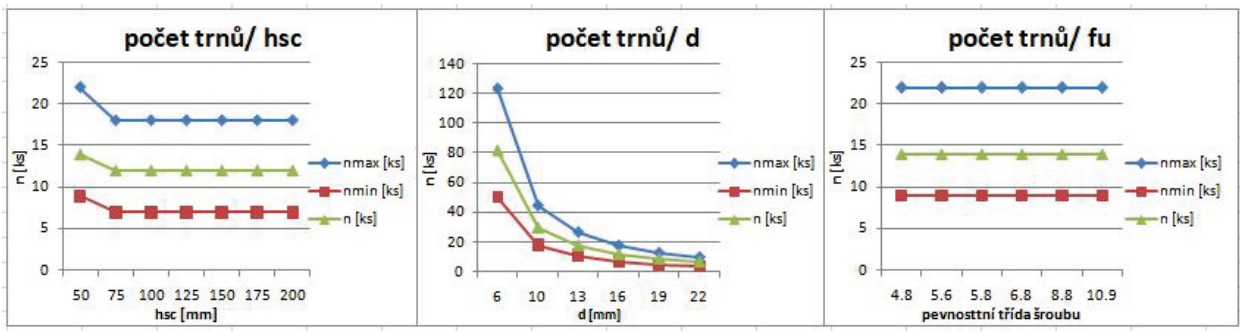

Obr.5 Grafy maximálního a minimálního počtu trnů a počtu trnů dle momentu v závislosti na změně rozměrů a materiálu trnů.

\section{DISKUZE}

Z předchozího výzkumu víme, že navýšení některého ze čtyř vstupních parametrů vyvolá nárůst momentové únosnosti. To samo o sobě zapř́ičiní pokles počtu trnů dle skutečného zatížení, jak je patrné na grafech na Obr. 3. Počet trnů dle zatížení má smysl, pouze pokud se jeho hodnota pohybuje mezi hodnotou pro plné spřažení a minimální hodnotou danou dle konstrukčních podmínek. Změnou výšky betonové desky se změní pouze ohybová únosnost a ostatní veličiny zůstávají konstantní. Z toho důvodu zůstává počet trnů nutný pro plné spřažení i minimální počet trnů stále stejný. Změna pevnostní třídy jako jediná ze čtyř zkoumaných proměnných má vliv na únosnost trnu. Se zvýšením pevnosti se zvýší i odolnost trnu. Ta narůstá, dokud nepřesáhne hodnotu danou první podmínkou ve vzorci a poté zůstává na konstantní úrovni. Funkce počtu trnů má stejný průběh pro spřahovací prostředky dle momentu i maximální a minimální hodnoty, jelikož se liší pouze rozdílem stupně 
smykového spojení, který se se změnou pevnosti betonu nemění. Naopak při změně meze kluzu oceli, může stupeň smykového spojení narůstat, jelikož mez kluzu $f_{\mathrm{y}}$ jako jediná z proměnných vystupuje ve vztahu (8), proto se zde s narůstající mezí kluzu rychleji zvětšuje i minimální počet trnů. Změna oceli, ale vyvolá i posun neutrální osy v průřezu a zvětšení smykové síly působící na trn. Jak bylo dříve zmíněno, vztah (4) byl navržen za předpokladu plné plastifikace, $\mathrm{z}$ toho důvodu zde dochází $\mathrm{k}$ poměrně rychlému nárůstu počtu trnů pro plné spřažení. Když se bude uvažovat se skutečným zatížením na nosníku, bude se snižovat počet trnů, ale brzy je tato hodnota limitována právě minimálním dovoleným počtem trnů. Obdobná situace nastává i při změně ocelového profilu, pouze s tím rozdílem, že zde minimální hodnota stupně smykového spřažení zůstává konstantní. Počet trnů na konkrétním nosníku je zapsán v Tab. 1. a názorně ukázán v grafu na Obr. 4. Zde je krásně patrné, jak se při změně betonu ustálí hodnota trnů v okamžiku, kdy pevnost trnů je určena dle první podmínky ve vztahu (1) a stejně tak lze pozorovat, kdy u změny pevnosti a velikosti ocelového profilu ustane pokles trnů dle skutečného zatížení a dále roste kvůli splnění podmínky pro minimální stupeň vyztužení.

Co se týče změn parametrů samotného spřahovacího prostředku, tak z grafu na Obr. 5 je vidět, že průběh počtu dle skutečného zatížení, ale i maximálního a minimálního počtu trnů má stejný průběh, jelikož změna těchto parametrů nemá vliv na stupeň smykového spojení. Logicky s rostoucí šírkou dříku dosahuje spřahovací prvek větší tuhosti a tím je jich zapotřebí menší počet. Výška prvku má vliv pouze na součinitel $\alpha$, který je dán poměrem výšky prvku $h_{\mathrm{sc}}$ a průměru dříku $d$. S rostoucí výškou roste hodnota součinitele a tím i únosnost spřahovacího prvku. Součinitel alfa, je však shora omezen hodnotou 1,0 a po překročení této hodnoty už nemá větší výška vliv na únosnost. Zajímavé je, že změnou pevnosti spřahovacího prvku nemusí dojít $\mathrm{k}$ navýšení únosnosti prvku, pokud nebudou použity betony vyšších pevnosti, aby převážila první podmínka ze vztahu (1).

\section{ZÁVĚR}

Z výsledků studie je patrné, že změna parametrů spřaženého nosníku má významný vliv na počet spřahovacích prvků. Zatímco při větší tloušt'ce betonové desky či větší pevnosti betonu počet trnů klesá, dokud se nezastaví na konstantní hodnotě minimálního dovoleného počtu, tak při změně materiálu nebo velikosti ocelového profilu může sice z počátku dojít ke snížení nutného počtu trnů, ale se zvětšující se hodnotou vstupní veličiny začne počet trnů stoupat $\mathrm{v}$ důsledku limitu minimálního počtu trnů. Ze změn parametrů spřahovacího prostředku má nejvýraznější vliv změna průměru dříku, jehož kvadrát se vyskytuje v obou podmínkách únosnosti. Změna výšky trnu má pouze omezený vliv v závislosti na jejím poměru ku průměru dříku a změna materiálu trnu má omezený vliv dle kombinace s ostatními proměnnými. Tento výzkum slouží jako první fáze při zkoumání spřahovacích prostředků. V další fázi by trny měli být nahrazeny slepými šrouby a porovnány výsledky.

\section{Poděkování}

Př́íspěvek byl vypracován v rámci řešení projektu Specifického vysokoškolského výzkumu na Fakultě stavební Vysokého učení technického v Brně č. FAST-J-21-7474.

\section{Použité zdroje}

[1] C ČSN EN 1994-1-1: Eurokód 4: Navrhování spřažených ocelobetonových konstrukcí - Č́st 1-1: Obecná pravidla a pravidla pro pozemní stavby, Praha: Český normalizační institut; 2006.

[2] HRABOVSKÁ, K., BŘEČKA, J., Teoretický výzkum optimalizace rozměrů a volby pevnosti materiálu u ocelobetonových spřažených nosníků, Juniorstav 2021 Sborník př́íspěvků, str. 283-288, rok vydání 2021, ISBN: 978-80-86433-75-2

[3] SAMEC, J., STUDNIČKA J., Model chování spřahací lišty při statickém namáhání, Stavební obzor, 6/2004, str. 165-170

[4] PATEL, V. I., UY, B., PATHIRANA, S. W., WOOD, S., SINGH, M., TRANG, B. T., Finite element analysis of demountable steel-concrete composite beams under static loading, Advanced Steel Construction - Vol. 14 No. 3, pp. 392-411 (2018), http://ascjournal.com/down/vol14no3/Vol14No3_5.pdf

[5] LOQMAN, N., SAFIEE, N. A., ABU BAKAR, N., NASIR, N. A. M., Structural Behavior of SteelConcrete Composite Beam using Bolted Shear Connectors: A Review, MATEC Web of Conferences 203, 06010, ICCOEE 2018, https://doi.org/10,1051/matecconf/201820306010

[6] TRAN, M.-T., VAN DO, V. N., NGUYEN, T.-A., Behaviour of Steel-Concrete Composite Beams using Bolts as Shear Connectors, CUTE 2018, IOP Conf. Series: Earth and Environmental Science 143 (2018) 012027, doi:10.1088/1755-1315/143/012027 